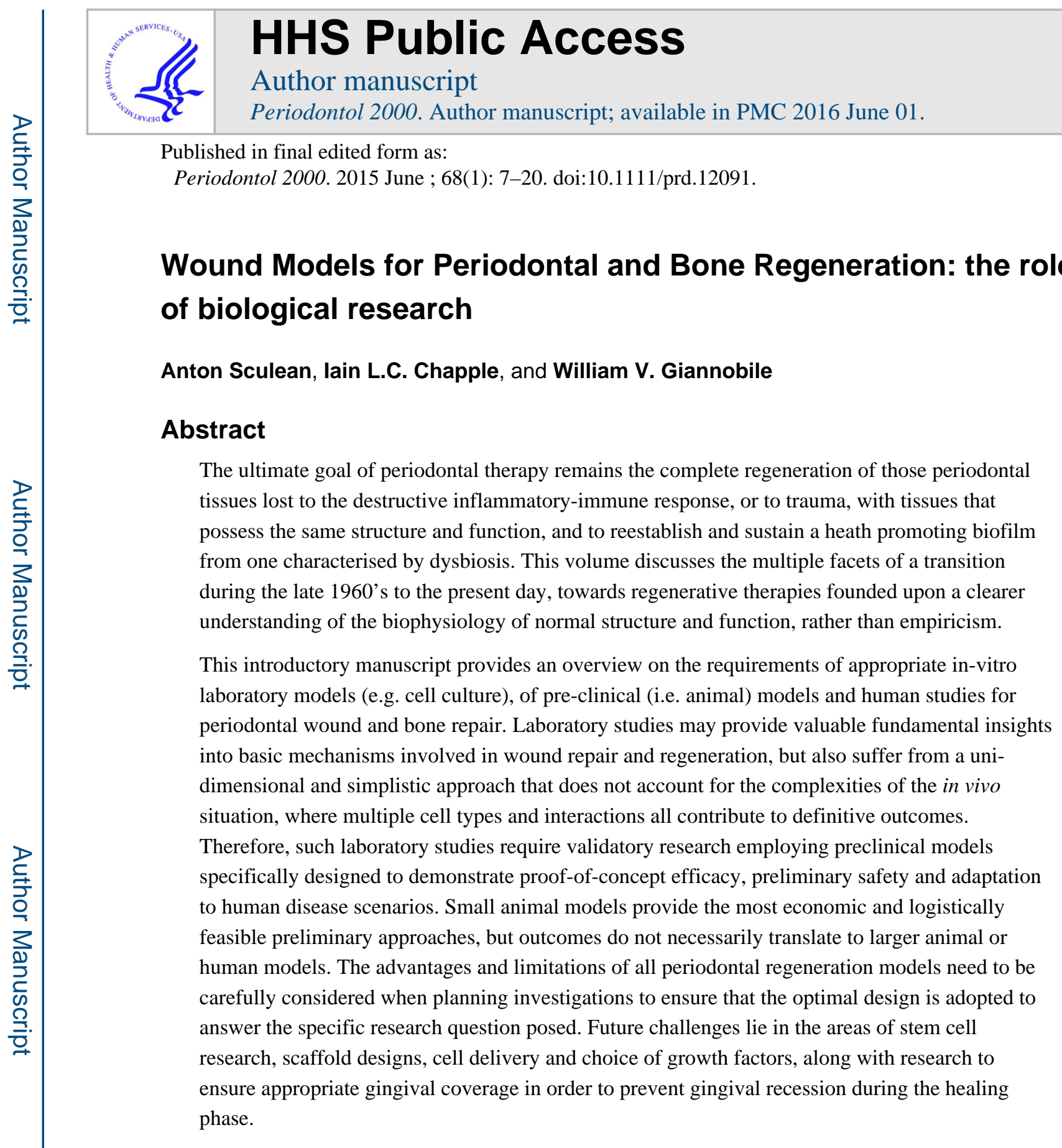

The treatment of periodontal diseases represents a significant health care challenge (143) and since the genesis of human research endeavours in periodontology, the ultimate therapeutic goal has been to completely rebuild those tissues lost to the disease process with tissues that are structurally and functionally the same. Early attempts at regeneration were empirical, largely based upon clinical experience, and included the utilisation of scaling and root planing combined with soft tissue curettage or the use of various flap procedures and materials for "bone grafting" $(17,30,94,99,100,114)$. Such approaches occasionally resulted in clinical improvements expressed as probing depth reductions or bone defect fill, which at the time were termed "new attachment" or "regeneration" $(43,98,111,140)$. However,

Corresponding author: anton.sculean@zmk.unibe.ch. 
histological studies in animals and humans subsequently demonstrated that such methods did not predictably result in the formation of periodontal ligament, root cementum and bone $(31,32,78,129)$.

A proper understanding of the basic biological mechanisms involved in periodontal wound repair and regeneration requires the assessment of the macroscopic, microscopic, cellular and molecular components of the healing process (Fig. 1). To best determine the molecular mechanisms that guide tissue neogenesis during wound repair and regeneration, the use of basic science (laboratory) studies needs to be translated to the clinical arena. The bridging of discovery research to the clinic and eventual adoption to clinical practice requires preclinical animal model studies to determine the safety and early stage effectiveness of new technologies. This volume of Periodontology 2000 highlights advances from a myriad of approaches to comprehensively determine how wound healing models are employed in oral, periodontal and craniofacial tissue regeneration. In this introduction we present those requirements for the use of preclinical research in periodontal wound repair as well as identifying limitations of the work that would need to be addressed prior to human studies in preclinical models or directly in the human clinical trial setting (due to limitations of animal models to replicate the human clinical disease scenario). Finally, the key findings of the reviews within this volume are summarised.

\section{A historical perspective}

A recent history of periodontal regeneration over the past century has been recently summarised (44). In the modern era of regenerative biology, pioneering work was made in the late 1960's by Tony Melcher, who demonstrated advances through his studies into the biology of periodontal would healing. In 1969 Melcher distinguished the processes or "repair" and "regeneration" (82-84) and in 1976 he postulated that "the first cells to repopulate a root surface will dictate the nature and quality of tissue that forms there" (82). Half a century later, it is perhaps worthwhile reflecting upon the extent to which our current treatment concepts are biologically based as Melcher taught, or whether we still to some degree at least, fall into the trap of empiricism when aiming to regenerate periodontal defects.

Important questions that arise when exploring biological approaches to periodontal regeneration include:

- Is there a rationale and role for pre-clinical (animal) models to evaluate the biological potential of novel regenerative technologies and what is the clinical relevance of such models?

- Are regenerative materials that have been validated using pre-clinical models also effective in the human situation?

- What are the current concepts in managing angular (intrabony), furcation and recession defects around teeth?

- What options are available for managing defects caused by infection around dental implants? 
- What is the role of "surgical technique", including flap management and suturing, in determining improvements in clinical outcomes?

Several decades ago, due to a paucity of knowledge of the etiology and pathogenesis of periodontitis, it was believed that bone was the only tissue that played a role in supporting the tooth within the alveolus, and that the "diseased bone" was primarily responsible for the presence of angular (intra-bony) or furcation defects arising in periodontitis patients $(88,105)$. Such beliefs consequently led to the development of treatment protocols that focussed primarily on filling the "holes" with great variety of bone grafting materials. The latter were largely non-resorbable and thus effectively acted inactive biological fillers. Moreover, the majority of studies evaluating the effects of different surgical procedures aimed at defect fill with bone grafts, only employed clinical outcome measures such as probing pocket depth, probing attachment level, radiological analysis and, direct visualisation following surgical reentry procedures $(21,43,52,87,98,104,106,111)$. However, such approaches did not facilitate the determination of true periodontal regeneration, an outcome that requires systematic histological investigation. Subsequently, pivotal histological studies provided evidence that the outcomes of periodontal probing were strongly correlated with the level of soft tissue inflammation present, and as such may not necessarily reflect genuine tissue regeneration. For instance, if the gingiva is inflamed the tip of the probe will easily penetrate the pocket base through the connective tissues and to a level apical to the base of the pocket. If inflammation is reduced, the gingival connective tissues contract and demonstrate greater resistance to probing, thus preventing the tip of the probe from reaching the pocket base $(12,77,137)$.

Subsequent research using different grafting materials in periodontal defects, led to improvements in probing pocket depths as well as radiographic bone fill, giving the impression that true regeneration had occurred. Similarly, hard tissue infill detected during clinical re-entry procedures, was interpreted as proof of periodontal regeneration. A greater understanding of the biology of periodontal wound healing and regeneration commenced with the publication of a series of studies employing pre-clinical models with ligatureinduced periodontitis, in order to mimic chronic periodontal defects in humans. The results were somewhat disappointing and demonstrated that all treatment procedures aiming to regenerate periodontal tissues, including root planing and soft tissue curettage, and indeed modified Widman flap surgery with or without various bone grafts, consistently resulted in the formation of a long junctional epithelium on the instrumented root surface without any, or with limited formation of cementum with inserting periodontal ligament fibres (32). Moreover, if bone formation was evident histologically in some of the defects, an epithelial lining was always interposed between the newly formed bone and the root surface. These findings were later confirmed in several independent studies demonstrating that, the majority of approaches to periodontal regeneration, remained empirical in nature and lacked a foundation in biological science $(53,64,101,134)$.

Almost simultaneously with the experiments of Caton and co-workers were Melcher's reports from a series of elegant experiments that had led him to hypothesize that the cells responsible for periodontal regeneration were resident within the periodontal ligament and not in the bone itself (82). Thus, Melcher proposed the periodontal ligament as the key tissue 
responsible for periodontal regeneration. This hypothesis was later tested in a series of animal studies that provided evidence that only the granulation tissue originating from the periodontal ligament had the capacity to form new cementum, and eventually new alveolar bone, whilst the connective tissue originating from the gingival flap or the alveolar bone did not promote true periodontal regeneration, as evidenced by the formation of new cementum with inserting collagen fibres and new alveolar bone $(55,61,63,64,76,89-91)$.

Knowledge obtained from such pre-clinical (animal) models led to the development of the treatment concept termed "guided tissue regeneration" $(47,48,93)$. The guided tissue regeneration concept built upon Melcher's thesis that the first cells to populate the root surface would dictate the tissue that formed there. Therefore barrier membranes were developed as barriers to the down growth of the junctional epithelium, whist at the same time occluding the ingress of fibroblasts from the gingival connective tissues lining the surgical flap. Such a dual barrier facilitated those cells arising from the intact periodontal ligament to repopulate the debrided root surfaces. This series of well-designed and reported experiments (62) is just one example of how a deeper biological understanding of tissue structure and function may ultimately translate into a clinically relevant treatment concept, once initially tested in animal models. Furthermore, these landmark studies highlighted the need for a greater understanding of the biological processes involved in wound healing, prior to developing novel treatment concepts, and the potential dangers of introducing treatment methods without previously evaluating those concepts in pre-clinical models.

\section{Periodontal regeneration - myth or a reality?}

A plethora of different surgical techniques involving the implantation of various types of bone graft and/or bone substitutes, root surface demineralization procedures, guided tissue regeneration, use of growth/ differentiation factors, enamel matrix proteins, or various combinations thereof, have been employed in order to achieve periodontal regeneration, and have been shown to promote periodontal regeneration in animals $(62,72,80,104,4,133,134)$. Despite positive observations in animal models and successful outcomes reported for many of the available regenerative techniques and materials in patients, including histological evidence, robust information on the degree to which reported clinical improvements reflect true periodontal regeneration, remains limited (19).

When analysing the literature on human studies evaluating healing following the use of various regenerative materials for human intrabony defects, it is apparent that periodontal regeneration in humans can be achieved to a variable extent with several materials including guided tissue regeneration, biological factors, certain types of grafts and numerous combinations of the aforementioned (126). In contrast to the findings in animal studies, the implantation of alloplastic materials alone has demonstrated at best, limited, and frequently no periodontal regeneration in humans $(19,56,126)$. These findings appear to indicate that complete periodontal regeneration in humans is possible in certain clinical situations and with a limited number of regenerative materials or their combinations. Whilst studies of human defects may provide important information on the biological potential of various regenerative protocols and biomaterials, the information obtained from such studies needs to 
be carefully interpreted in the light of the available evidence from preclinical and clinical studies.

\section{What are the benefits and limitations of pre-clinical models for research into periodontal regeneration and wound healing?}

Wound healing principles need to be carefully considered in the development of biomimetic materials that can provide an appropriate microenvironment for tissue formation (74). These materials are used as matrices for delivery of cells, molecules or scaffolding constructs for eventual clinical use. Based on these needs, preclinical studies have enabled the initiation of clinical investigations that have resulted in the approvals of new medical devices or drugs that promote periodontal tissue repair (46). Preclinical study plans must be adapted for the specific purpose of the investigation (mechanistic or outcomes that will link to a surrogate clinical measure). An example of a mechanistic goal might be to determine the role of a newly discovered cell adhesion molecule during the induction of experimental periodontitis in a genetically-modified animal (knock-out or transgenic) model. By contrast, a new drug to stimulate periodontal ligament formation may be injected into the gingival tissues to histologically examine the soft tissue repair processes at the microscopic level. A preclinical model is used since this approach is not readily achievable in humans (at least in a meaningful, adequately powered study). Moreover, the objectives of a preclinical study must relate to the efficient and effective design of a reconstructive therapy. The choice of the endpoints is therefore a critical issue in the study design. Overall, planning a preclinical study to evaluate regenerative devices requires decisions about animal species, defect type, the study endpoint and study duration (95). Moreover, endpoints must be defined to estimate the sample size necessary to achieve the desired power (20). Considering the size of the defects as well as morphological changes related to the anatomical defect that can occur over time can help to estimate the appropriate study duration.

The selection of preclinical models considers the differing anatomy and healing characteristics of rodents and larger animals (128). A summary of commonly used preclinical models to evaluate periodontal reconstructive therapies, highlighting those related to devices and biologics is illustrated in Tables 1 and 2. Many new regenerative approaches that strive to demonstrate a proof-of-concept or early stage mechanistic understanding of the wound healing process will employ small animal models as screening tools prior to embarking on larger animal studies (131).

\section{Preclinical investigations to promote the development of new regenerative medicines}

It typically takes over 10 years and more than 350 Million US dollars to bring a new drug from the laboratory to the market (59). Testing in the laboratory and preclinical phases can take 3-4 years prior to applying to the US Food and Drug Administration, European Medicines Agency or other national-international regulatory authorities to launch clinical investigations (Fig. 2). Only one in 1,000 compounds that undergoes this initial phase of testing will ever reach the next phase of testing in humans (33). Assuming regulatory approval for human testing following submission of an Investigational New Drug Application, three phases of clinical trials typically follow: 
- Phase I that establish safety of a drug;

- Phase II which gain preliminary information relative to the efficacy of the agent;

- Phase III is designed to be randomized and controlled in order to determine the effectiveness of the biological agent (97).

\section{Common animal models used in periodontal wound healing research}

A variety of different animal models such as rats, dogs, and non-human primates have been used in periodontal regenerative studies (95). The rat periodontal model has been frequently employed for bone regeneration studies $(49,54,57,67)$. It is valuable as a screening model for regenerative molecule assessment due to cost-effectiveness, ease of handling, etc. However, the typical defect size is relatively small making visualization challenging, and requiring the use of surgical microscopes for defect creation (128). Large animal models, such as the canine or non-human primate, are a logical next step. The canine wound healing kinetics and tooth anatomy has many similarities to the human situation $(142,143)$. Nonhuman primates are highly desirable to evaluate the safety and efficacy of new molecules because their anatomical and biological features are very close to humans (68). However, their high cost and handling difficulties prevent them from being utilized more frequently. The preferred animal model should be selected according to study requirements such as periodontal, oral implant, sinus floor augmentation, and alveolar ridge reconstruction.

A study should not be proposed if a clear end-point goal is not established that will eventually have an impact on human health or disease. Animal-based research has led to significant improvements in quality-of-life for many patients $(13,140)$. However, these advances must result from the humane use and care of animals employed in such research. The field of periodontal regenerative medicine has advanced to better report and design animal studies aimed to truly advancing the field. The National Centre for the Replacement, Refinement and Reduction of Animals in Research, a UK Government sponsored organization has documented overall marginal quality standards with respect to the documentation, design and reporting of animal studies in research (65). These findings have led to the development of guidelines for the reporting of preclinical studies to improve their quality and overall, to reduce the use of animals in research. The ARRIVE guidelines (Animals in Research: Reporting In Vivo Experiments), have been developed using the CONSORT Statement as their foundation (66). These guidelines have now become a requirement for the publication of preclinical research in many scientific journals. The guidelines support animal ethical bodies to improve the overall quality of preclinical research. Further, organizations such as the European Federation of Periodontology have addressed this issue in several recent publications on periodontal and peri-implant wound healing $(16,121,125,138)$.

\section{Future applications of periodontal wound healing models}

The use of pre-clinical animal models, typically under good laboratory practice settings, is an important component in the development of new biomaterials for clinical trials (117). In vivo models are in general superior to in vitro investigations to aid in the understanding of the complex molecular, cellular and tissue reactions that occur in response to delivered 
regenerative molecules. Despite the limitations of pre-clinical models for human disease, in vitro investigations for the simulation of human disease continue to remain inappropriate prior to testing in humans. The increased growth of development of biologics and devices for application in periodontal regenerative medicine requires a thorough examination of when and how the appropriate endpoints can be evaluated prior to entry into human clinical trial testing. With continued innovations in more non-invasive ex vivo technologies, the needs for pre-clinical testing will only decrease.

However, optimized animal models are still necessary for the evaluation of wound healing promoters prior to human testing. Limitations include obvious differences in the host response, disease development and anatomical differences among animals and humans. Models that can better implement risk factors of disease development known to affect periodontal wound healing such as smoking, diabetes and microbial infection may aid in the continued refinement of pre-clinical animal models before embarking upon expensive human trials. As the personalized medicine field continues to evolve, host-susceptibility and identification of those people who best respond to wound healing modifiers may provide more translatable outcomes to individual patients. The ultimate result of enhanced preclinical testing will greatly advance patient care for the public and aid in the better understanding of wound repair mechanisms.

\section{What is the current "state of the art" in periodontal wound and bone healing?}

The first reviews in this volume address the role of the various aforementioned models employed to evaluate novel treatment approaches for periodontal, bone and peri-implant wound healing and their potential role in informing the implementation of clinical therapy in humans $(41,44,60,123,131)$.

Preclinical studies are usually performed to evaluate proof-of-principle concepts, safety, and possible unwanted effects of candidate biological agents or bone biomaterials, prior to proceeding into clinical testing $(45,86,95)$. Selection of the appropriate animal species and wound healing model is largely dependent upon the research question or the disease model. For example, models involving small animals have been developed largely for screening bone biomaterials for their potential to enhance bone formation. Since, no single model can completely mimic the anatomical, physiological, biomechanical, and functional environment of the human mouth and jaws, the results obtained in small animals need to be validated in larger animals (e.g. dogs, mini-pigs or monkeys) whose dento-alveolar anatomy resembles more closely that of humans.

Following the application of the guided tissue regeneration principle for treatment of periodontal defects, the same principle was used in a number of pre-clinical and clinical studies for the regeneration of bone defects or for the augmentation of deficient sites. For these techniques, the term "guided bone regeneration" was adopted, pointing to the biological rationale based on the mechanical exclusion of neighbouring soft tissues surrounding the bone defects, in order to allow only osteogenic cells derived from the margins of the bony defect to repopulate the wound area. This biological principle, also 
based upon Melcher's theories was first tested in smaller animal models such as rats and rabbits, and confirmed later in larger animals (e.g. dogs and monkeys) (4,37-40,70).

An important issue when testing the guided bone regeneration principle is the use of the so called "critical size defect", indicating bone defects that do not heal spontaneously with osseous fill but with fibrous connective tissue. Critical size defect models involve healing of orthotopic bone sites such as the mandible or the calvarium, and thus allow the evaluation of bone grafts and other bone regenerative modalities in a standardized and discriminative manner to provide "proof-of-principle" $(14,38,58,70,116,117,136)$. Since it has been repeatedly demonstrated that guided bone regeneration can successfully regenerate critical size defects, nowadays the use of such experimental models for evaluating the effect of different treatment modalities for bone regeneration is recommended, as discussed by Donos et al. in this volume (41).

The guided bone regeneration principle has been successfully applied in the treatment of patients exhibiting different types of bone defects leading to a substantial increase in the cases of dental implant therapy; cases that were previously not feasible due to a lack of bone at the recipient site $(23-26,51,92)$. Taken together, these animal experiments serve as a beautiful example of the importance of preclinical models (phase-1 studies) in translational regenerative dental research.

The successful integration of guided bone regeneration principles into clinical practice over the last two decades has led to a substantial increase in the number of dental implants being placed and associated bone augmentation procedures. This has coincided with an ageing population whose expectations of tooth replacement with fixed prostheses have also increased $(81,130)$. However, there has been a coincident increase in the proportion of the population suffering from age-related chronic diseases and conditions such as diabetes and osteoporosis $(50,69,103)$. Their impact upon bone regeneration procedures related to implant rehabilitation is largely un-explored and consequently, there is a pressing need to evaluate different bone regenerative techniques in pre-clinical models, to help optimise the treatment of patients affected by such systemic conditions. Donos et al. (41) discuss these issues in their review. Interestingly, recent data from preclinical models indicate that, in osteoporotic animals, a hydrophilic barrier/implant surface may counteract the negative effect of osteoporotic-like conditions, whilst the use of guided bone regeneration appears to create an environment that facilitates bone formation in experimentally-induced diabetes and osteoporosis $(73,79)$. Despite the fact that, at present, it is difficult to draw any conclusions regarding the extent to which systemic conditions may affect bone metabolic status, vascularisation and healing capacity, the use of various preclinical models simulating systemic health and disease are of utmost clinical relevance for developing new concepts that enable de novo bone formation via guided bone regeneration in medically compromised patients.

\section{The extraction socket as a wound healing model}

Tooth extraction is one of the most common surgical procedures performed on humans, yet reviewing decades of published literature, it is remarkable to note that very little was known about the biological processes that take place during socket healing until recently. Studying 
the simplest of wound healing models (i.e. the extraction socket), has provided profound insights in the temporal sequence of healing events that follow tooth extraction $(6,10,11,29$, 146).

Studies by Araujo \& colleagues (8) have demonstrated that, the overall wound healing events described histologically in dogs are remarkably similar to humans, despite the fact that bone modelling and remodelling during socket healing is 3-5 times quicker in dogs. Such findings subsequently led to the development of clinical protocols associated with tooth extraction. For example, today it is recommended that tooth extraction is planned and performed, with attention paid to the subsequent anticipated changes in ridge width and height following this intervention. As a result, there is frequently an indication to consider adjunctive therapies in order to compensate for such changes, particularly in cases when further treatment such as dental implant placement is planned $(9,75)$.

\section{Pre-clinical and human models to study osseointegration and management of peri-implant infections}

The use of preclinical (animal) and human models has been shown to provide valuable information regarding our understanding of the healing of hard and soft tissue integration around titanium dental implants $(1-3,18,42,71,85,146)$. Such healing results from a complex cascade of biological events that are initiated by the surgical intervention. The temporal sequence of healing events that culminate in osseointegration has been elucidated in animals and humans. Implant placement into alveolar bone induces a cascade of healing steps, commencing with clot formation and continuing with bone maturation in direct contact with the implant surface. Salvi and colleagues (112) demonstrate that osseointegration is associated with a decrease in inflammation and an increase in osteogenesis-, angiogenesis- and neurogenesis-related gene expression during the early stages of wound healing. The attachment and maturation of the soft tissue complex to implants (i.e. epithelium and connective tissue) is established 6-8 weeks following surgery (126). Moreover, the use of preclinical data has provided important insights into the etiology, pathogenesis and therapeutic approaches to peri-implant diseases, since established lesions in animals have shown many features in common with those analyzed in human biopsy material $(5,27,28,120,121,122)$.

The review of Romanos (107) provides some evidence that immediate loading of augmented ridges may improve bone stability following implant placement and Schwarz et al. (123) discuss the utility of animal models in developing therapeutic approaches to implant failure (96,108-110,123). Renvert \& Polyzois (102) discuss the limitations of existing approaches to managing peri-implant mucositis and peri-implantitis in humans and conclude that the most important factor in managing implant failure is patient self-performed oral hygiene.

\section{What can in vitro models offer for a better understanding of periodontal wound and bone healing?}

In order to improve and further develop treatment strategies aiming to regenerate soft and hard tissues at natural teeth and dental implants, it is important to acquire a thorough understanding of the characteristics and the role of different wound healing components 
involved in the complex processes of wound healing and repair, such as cells, matrices, molecules and genes, as well as the mechanisms controlling their function. Since these processes are complex, it is extremely difficult to understand and define the role of each component in determining the final outcome. Furthermore, in animal models that aim to simulate a certain clinical situation, the influence of individual components in the wound healing cascade is difficult to assess. Such models are also expensive and frequently difficult to work with. Thus, in order to understand a certain mechanism, or prior to testing a specific biological principle or biomaterial in animals, it makes sense to adopt a stratified approach by answering single, well defined questions using specifically designed laboratory models.

A plethora of in vitro models have been described and developed to mimic the wound healing events of soft tissues (e.g., oral epithelia or oral fibroblasts) or to measure proliferation, attachment and migration, gene expression and differentiation into a mineralizing phenotype, as well as biomineralization of periodontal ligament fibroblasts or progenitors, osteoblasts or osteoprogenitors and cementoblasts. Other in vitro studies have utilized various gene transfer models, models designed to evaluate the effect of implant surface modifications on cellular behaviour, or models that address biocompatibility and degradation of different types of resorbable membranes $(34,141)$.

Despite the fact that, in general, such laboratory-based models are less expensive and easier to perform compared to animal experiments, they differ markedly from the in vivo situation since they typically employ single cell types without the surrounding matrix or other relevant cell types, and without the influence of external factors. Therefore, results obtained using such models often provide critical mechanistic and biological plausibility insights. These studies lay the foundation for potential clinical application in more applicable preclinical and clinical studies on the disease and injury processes.

\section{Improved clinical outcomes through an improved understanding of biology}

There is little doubt that research conducted over the last 25 years into the bio-physiology of periodontal and tooth socket healing, has informed the development of novel approaches to restoring lost periodontal tissues and bone $(8,44,135)$. In the laser field, comprehensively reviewed by Aoki and colleagues (7), a greater understanding of the role of certain wavelengths in removing soft and hard deposits, killing bacteria and improving wound healing, has led to the application of lasers and of laser-based photodynamic therapy in clinical periodontal care. Some positive effects such as the reduction of inflammation (less bleeding on probing) following the additional application of photodynamic therapy have been demonstrated in randomized controlled clinical studies to be statistically significant and clinically relevant and are thus such approaches are frequently used in the maintenance phase $(15,35,115,135)$. By contrast, it is clear that laser therapy has thus far failed to demonstrate improved periodontal outcomes over and above those achieved by traditional instrumentation (119). Such negative findings are also important to report, since they save the effort and costs involved in repeating clinical trials of the same, and open up opportunities to explore the utility of different wavelengths and protocols.

Other examples where tissue regeneration techniques that have been developed based upon learnings from biological research have improved clinical outcomes include intrabony 
defects, furcation lesions (see reviews by Cortellini \& Tonetti [36], and Sanz et al. [113]) and recession defects (see Zucchelli et al. [144]). The novel concepts reported in these reviews have evolved following in vitro and animal studies, that have informed a better understanding of periodontal and bone wound healing and of the role and use of various biomaterials on periodontal ligament cells, gingival fibroblasts and bone cells. These techniques combine the use of surgical flaps and suturing techniques (see Burkhardt \& Lang [22]) designed to improve blood clot protection and to enhance wound stability, and the use biologically potent biomaterials.

Stem cell research holds great promise for the future of periodontal regeneration, but multiple challenges remain including the development of appropriate matrices to deliver cell therapies, appropriate growth factor combinations which facilitate physiological healing processes in what is ultimately a potentially "infective" healing environment. The latter is a challenge that is frequently overlooked or under-estimated, but involves stimulating the body's physiological wound repair processes within a complex milieu of microbial and host signalling between innate and acquired immune systems and a colonizing microbiome.

Similar challenges face bone regenerative procedures around failing implants, which lack a periodontal ligament (and thus a vital source of undifferentiated stem cells) and also differ in terms of the connective tissue fibre anatomy within the investing soft tissue cuff. Here, emerging evidence indicates that early outcomes of bone regeneration are more predictable when the implant fixture is re-covered by soft tissues to facilitate healing in a "closed system", where microbial colonisation is not a complication. Nevertheless, longer-term studies are needed in this emerging field in order to better understand the biology of healing around implants that have suffered peri-implantitis, and also to understand the nature of the primary process of peri-implantitis at the tissue level. It appears that we are now at the end of the beginning of research into periodontal and bone regeneration and understanding the pathobiology of periodontitis and peri-implantitis is fundamental to enable the design of regenerative strategies and technologies, that rather than the generic approaches of today.

\section{Acknowledgments}

The collaborations from Qiming Jin, Jim Sugai, Hector Rios, Reinhard Gruber, Yang-jo Seol, Gaia Pellegrini, and Darnell Kaigler are greatly appreciated. Dr Giannobile's work was supported in part by NIH/NIDCR DE 13397.

\section{References}

1. Abrahamsson I, Berglundh T, Glantz PO, Lindhe J. The mucosal attachment at different abutments. An experimental study in dogs. Journal of clinical periodontology. 1998; 25:721-727. [PubMed: 9763327]

2. Abrahamsson I, Berglundh T, Moon IS, Lindhe J. Peri-implant tissues at submerged and nonsubmerged titanium implants. Journal of clinical periodontology. 1999; 26:600-607. [PubMed: 10487311]

3. Abrahamsson I, Zitzmann NU, Berglundh T, Linder E, Wennerberg A, Lindhe J. The mucosal attachment to titanium implants with different surface characteristics: an experimental study in dogs. Journal of clinical periodontology. 2002; 29:448-455. [PubMed: 12060428]

4. Alberius P, Dahlin C, Linde A. Role of osteopromotion in experimental bone grafting to the skull: a study in adult rats using a membrane technique. Journal of oral and maxillofacial surgery : official journal of the American Association of Oral and Maxillofacial Surgeons. 1992; 50:829-834. 
5. Albouy JP, Abrahamsson I, Persson LG, Berglundh T. Spontaneous progression of ligatured induced peri-implantitis at implants with different surface characteristics. An experimental study in dogs II: histological observations. Clinical oral implants research. 2009; 20:366-371. [PubMed: 19309770]

6. Amler MH. The time sequence of tissue regeneration in human extraction wounds. Oral surgery, oral medicine, and oral pathology. 1969; 27:309-318.

7. Aoki AMK, Schwarz F, Sculean A, Takasaki AA, Romanos GE, Taniguchi Y, Sasaki KM, Zeredo JL, Koshy G, Coluzzi DJ, White JM, Abiko Y, Ishikawa I, Izumi Y. Periodontal and peri-implant wound healing following laser therapy. Periodontol 2000. 2015 in press.

8. Araujo MG, Silva CO, Misawa M, Sukekava F. Alveolar socket healing: what can we learn? Periodontol 2000. 2015 in press.

9. Araujo MG, da Silva JC, de Mendonca AF, Lindhe J. Ridge alterations following grafting of fresh extraction sockets in man. A randomized clinical trial. Clinical oral implants research. 2014 in press.

10. Araujo MG, Lindhe J. Dimensional ridge alterations following tooth extraction. An experimental study in the dog. Journal of clinical periodontology. 2005; 32:212-218. [PubMed: 15691354]

11. Araujo MG, Lindhe J. Ridge alterations following tooth extraction with and without flap elevation: an experimental study in the dog. Clinical oral implants research. 2009; 20:545-549. [PubMed: 19515033]

12. Armitage GC, Svanberg GK, Loe H. Microscopic evaluation of clinical measurements of connective tissue attachment levels. Journal of clinical periodontology. 1977; 4:173-190. [PubMed: 268333]

13. Bachman, A. Ethical considerations for performing research in animals. In: Giannobile, WV.; Nevins, M., editors. Osteology guidelines for oral \& maxillofacial regeneration. London: Quintessence; 2011. p. 9-21.

14. Bartee BK, Carr JA. Evaluation of a high-density polytetrafluoroethylene (n-PTFE) membrane as a barrier material to facilitate guided bone regeneration in the rat mandible. The Journal of oral implantology. 1995; 21:88-95. [PubMed: 8699509]

15. Bassetti M, Schar D, Wicki B, et al. Anti-infective therapy of peri-implantitis with adjunctive local drug delivery or photodynamic therapy: 12-month outcomes of a randomized controlled clinical trial. Clinical oral implants research. 2014; 25:279-287. [PubMed: 23560645]

16. Berglundh T, Stavropoulos A. on behalf of Working Group 1 of the VIII European Workshop on Periodontology*Preclinical in vivo research in implant dentistry. Consensus of the eighth European workshop on periodontology. J Clin Periodontol. 2012; 39(12s):1-5. [PubMed: 22533943]

17. Beube FE. A study on reattachment of the supporting structures of the teeth. Journal of periodontology. 1947; 18:55-66. [PubMed: 20292525]

18. Bosshardt DD, Salvi GE, Huynh-Ba G, Ivanovski S, Donos N, Lang NP. The role of bone debris in early healing adjacent to hydrophilic and hydrophobic implant surfaces in man. Clinical oral implants research. 2011; 22:357-364. [PubMed: 21561477]

19. Bosshardt DD, Sculean A. Does periodontal tissue regeneration really work? Periodontol 2000. 2009; 51:208-219. [PubMed: 19878476]

20. Braun, TM. Research design and biostatistical considerations in preclinical research. In: Giannobile, WV.; Nevins, M., editors. Osteology guidelines for oral \& maxillofacial regeneration. London: Quintessence; 2011. p. 31-43.

21. Brunsvold MA, Mellonig JT. Bone grafts and periodontal regeneration. Periodontol 2000. 1993; 1:80-91.

22. Burkhardt R, Lang NP. Influence of suturing on wound healing. Periodontol 2000. 2015 (in press).

23. Buser D, Bornstein MM, Weber HP, Grutter L, Schmid B, Belser UC. Early implant placement with simultaneous guided bone regeneration following single-tooth extraction in the esthetic zone: a cross-sectional, retrospective study in 45 subjects with a 2- to 4-year follow-up. Journal of periodontology. 2008; 79:1773-1781. [PubMed: 18771381]

24. Buser D, Bragger U, Lang NP, Nyman S. Regeneration and enlargement of jaw bone using guided tissue regeneration. Clinical oral implants research. 1990; 1:22-32. [PubMed: 2099209] 
25. Buser D, Dula K, Lang NP, Nyman S. Long-term stability of osseointegrated implants in bone regenerated with the membrane technique. 5-year results of a prospective study with 12 implants. Clinical oral implants research. 1996; 7:175-183. [PubMed: 9002837]

26. Buser D, Ingimarsson S, Dula K, Lussi A, Hirt HP, Belser UC. Long-term stability of osseointegrated implants in augmented bone: a 5-year prospective study in partially edentulous patients. The International journal of periodontics \& restorative dentistry. 2002; 22:109-117. [PubMed: 12019706]

27. Carcuac O, Abrahamsson I, Albouy JP, Linder E, Larsson L, Berglundh T. Experimental periodontitis and peri-implantitis in dogs. Clinical oral implants research. 2013; 24:363-371. [PubMed: 23176551]

28. Carcuac O, Berglundh T. Composition of human peri-implantitis and periodontitis lesions. Journal of dental research. 2014; 93:1083-1088. [PubMed: 25261052]

29. Cardaropoli G, Araujo M, Lindhe J. Dynamics of bone tissue formation in tooth extraction sites. An experimental study in dogs. Journal of clinical periodontology. 2003; 30:809-818. [PubMed: 12956657]

30. Carranza FA, Carranza FA Jr. Current status of surgery of periodontal pockets. Revista odontologica. 1954; 42:511-521. [PubMed: 24543426]

31. Caton J, Nyman S. Histometric evaluation of periodontal surgery. I. The modified Widman flap procedure. Journal of clinical periodontology. 1980; 7:212-223. [PubMed: 6933162]

32. Caton J, Nyman S, Zander H. Histometric evaluation of periodontal surgery. II. Connective tissue attachment levels after four regenerative procedures. Journal of clinical periodontology. 1980; 7:224-231. [PubMed: 7000854]

33. Center for Drug Evaluation and Research (CDER). [Accessed June 8, 2011] The drug approval process. 2011. http://drugs.com/fda-approval-process.html

34. Chiquet M, Katsaros C, Kletsas D. Multiple functions of gingival and mucoperiosteal fibroblasts in oral wound healing and repair. Periodontol 2000. 2015 in press.

35. Chondros P, Nikolidakis D, Christodoulides N, Rossler R, Gutknecht N, Sculean A. Photodynamic therapy as adjunct to non-surgical periodontal treatment in patients on periodontal maintenance: a randomized controlled clinical trial. Lasers in medical science. 2009; 24:681-688. [PubMed: 18465191]

36. Cortellini P, Tonetti MS. Clinical concepts for regenerative therapy in intrabony defects. Periodontol 2000. 2015 (in press).

37. Dahlin C, Alberius P, Linde A. Osteopromotion for cranioplasty. An experimental study in rats using a membrane technique. Journal of neurosurgery. 1991; 74:487-491. [PubMed: 1993913]

38. Dahlin C, Gottlow J, Linde A, Nyman S. Healing of maxillary and mandibular bone defects using a membrane technique. An experimental study in monkeys. Scandinavian journal of plastic and reconstructive surgery and hand surgery / Nordisk plastikkirurgisk forening [and] Nordisk klubb for handkirurgi. 1990; 24:13-19.

39. Dahlin C, Linde A, Gottlow J, Nyman S. Healing of bone defects by guided tissue regeneration. Plastic and reconstructive surgery. 1988; 81:672-676. [PubMed: 3362985]

40. Dahlin C, Sandberg E, Alberius P, Linde A. Restoration of mandibular nonunion bone defects. An experimental study in rats using an osteopromotive membrane method. International journal of oral and maxillofacial surgery. 1994; 23:237-242. [PubMed: 7798697]

41. Donos N, Dereka X, Mardas N. Experimental models for guided bone regeneration in healthy and medically compromised conditions. Periodontol 2000. 2015 in press.

42. Donos N, Hamlet S, Lang NP, Salvi GE, Huynh-Ba G, Bosshardt DD, Ivanovski S. Gene expression profile of osseointegration of a hydrophilic compared with a hydrophobic microrough implant surface. Clinical oral implants research. 2011; 22:365-372. [PubMed: 21561478]

43. Ellegaard B, Loe H. New attachment of periodontal tissues after treatment of intrabony lesions. Journal of periodontology. 1971; 42:648-652. [PubMed: 4937566]

44. Giannobile WV. Treatment of periodontitis: destroyed periodontal tissues can be regenerated under certain conditions. J Periodontol. 2014; 85:1151-1154. [PubMed: 25168257]

45. Giannobile, WV.; Kaigler, D.; Nevins, M. Preclinical model development for the reconstruction of oral, periodontal and craniofacial defects. London: Quintessence; 2011. 
46. Giannobile, WV.; Kaigler, D.; Nevins, M. Preclinical model development for the reconstruction of oral, periodontal and craniofacial defects. In: Giannobile, WV.; Nevins, M., editors. Osteology guidelines for oral \& maxillofacial regeneration. London: Quintessence; 2011. p. 1-8.

47. Gottlow J, Nyman S, Karring T, Lindhe J. New attachment formation as the result of controlled tissue regeneration. Journal of clinical periodontology. 1984; 11:494-503. [PubMed: 6384274]

48. Gottlow J, Nyman S, Lindhe J, Karring T, Wennström J. New attachment formation in the human periodontium by guided tissue regeneration. Case reports. Journal of clinical periodontology. 1986; 13:604-616. [PubMed: 3462208]

49. Graves DT, Fine D, Teng YT, Van Dyke TE, Hajishengallis G. The use of rodent models to investigate host-bacteria interactions related to periodontal diseases. J Clin Periodontol. 2008; 35:89-105. [PubMed: 18199146]

50. Halter JB, Musi N, McFarland Horne F, Crandall JP, Goldberg A, Harkless L, Hazzard WR, Huang ES, Kirkman MS, Plutzky J, Schmader KE, Zieman S, High KP. Diabetes and cardiovascular disease in older adults: current status and future directions. Diabetes. 2014; 63:2578-2589. [PubMed: 25060886]

51. Hammerle $\mathrm{CH}$, Jung RE, Feloutzis A. A systematic review of the survival of implants in bone sites augmented with barrier membranes (guided bone regeneration) in partially edentulous patients. Journal of clinical periodontology. 2002; 29 (Suppl 3):226-231. discussion 232-223. [PubMed: 12787222]

52. Hiatt WH, Schallhorn RG. Intraoral transplants of cancellous bone and marrow in periodontal lesions. Journal of periodontology. 1973; 44:194-208. [PubMed: 4570483]

53. Horvath A, Stavropoulos A, Windisch P, Lukacs L, Gera I, Sculean A. Histological evaluation of human intrabony periodontal defects treated with an unsintered nanocrystalline hydroxyapatite paste. Clinical oral investigations. 2013; 17:423-430. [PubMed: 22552592]

54. Huang KK, Shen C, Chiang CY, Hsieh YD, Fu E. Effects of bone morphogenetic protein-6 on periodontal wound healing in a fenestration defect of rats. J Periodontal Res. 2005; 40:1-10. [PubMed: 15613073]

55. Isidor F, Karring T, Nyman S, Lindhe J. The significance of coronal growth of periodontal ligament tissue for new attachment formation. Journal of clinical periodontology. 1986; 13:145150. [PubMed: 3455947]

56. Ivanovic A, Nikou G, Miron RJ, Nikolidakis D, Sculean A. Which biomaterials may promote periodontal regeneration in intrabony periodontal defects? A systematic review of preclinical studies. Quintessence Int. 2014; 45:385-395. [PubMed: 24634903]

57. Jin Q, Anusaksathien O, Webb SA, Printz MA, Giannobile WV. Engineering of tooth-supporting structures by delivery of PDGF gene therapy vectors. Mol Ther. 2004; 9:519-526. [PubMed: 15093182]

58. Kaban LB, Glowacki J. Induced osteogenesis in the repair of experimental mandibular defects in rats. Journal of dental research. 1981; 60:1356-1364. [PubMed: 7016947]

59. Kaigler, D.; Fuller, K.; Giannobile, WV. Regulatory process for the evaluation of dental drugs, devices, and biologics. In: Giannobile, WV.; Burt, BA.; Genco, RJ., editors. Clinical Research in Oral Health. New York: Wiley-Blackwell; 2010. p. 55-78.

60. Kantarci A, Hasturk H, Van Dyke TE. Animal models for periodontal regeneration and periimplant responses. Periodontol 2000. 2015 in press.

61. Karring T, Isidor F, Nyman S, Lindhe J. New attachment formation on teeth with a reduced but healthy periodontal ligament. Journal of clinical periodontology. 1985; 12:51-60. [PubMed: 3855871]

62. Karring T, Nyman S, Gottlow J, Laurell L. Development of the biological concept of guided tissue regeneration--animal and human studies. Periodontol 2000. 1993; 1:26-35.

63. Karring T, Nyman S, Lindhe J. Healing following implantation of periodontitis affected roots into bone tissue. Journal of clinical periodontology. 1980; 7:96-105. [PubMed: 6929795]

64. Karring T, Nyman S, Lindhe J, Sirirat M. Potentials for root resorption during periodontal wound healing. Journal of clinical periodontology. 1984; 11:41-52. [PubMed: 6363461] 
65. Kilkenny C1, Parsons N, Kadyszewski E, Festing MF, Cuthill IC, Fry D, Hutton J, Altman DG. Survey of the quality of experimental design, statistical analysis and reporting of research using animals. PLoS ONE. 2009; 4(11):e7824. [PubMed: 19956596]

66. Kilkenny C, Browne WJ, Cuthill IC, Emerson M, Altman DG. Improving bioscience research reporting: the ARRIVE guidelines for reporting animal research. PLoS Biol. 2010; 8(6):e1000412. [PubMed: 20613859]

67. King GN, King N, Cruchley AT, Wozney JM, Hughes FJ. Recombinant human bone morphogenetic protein-2 promotes wound healing in rat periodontal fenestration defects. J Dent Res. 1997; 76:1460-1470. [PubMed: 9240382]

68. Klausen B. Microbiological and immunological aspects of experimental periodontal disease in rats: a review article. J Periodontol. 1991; 62:59-73. [PubMed: 2002433]

69. Kling JM, Clarke BL, Sandhu NP. Osteoporosis prevention, screening, and treatment: a review. J Womens Health (Larchmt). 2014; 23:563-572. [PubMed: 24766381]

70. Kostopoulos L, Karring T. Augmentation of the rat mandible using guided tissue regeneration. Clinical oral implants research. 1994; 5:75-82. [PubMed: 7918912]

71. Lang NP, Salvi GE, Huynh-Ba G, Ivanovski S, Donos N, Bosshardt DD. Early osseointegration to hydrophilic and hydrophobic implant surfaces in humans. Clinical oral implants research. 2011; 22:349-356. [PubMed: 21561476]

72. Lee J, Stavropoulos A, Susin C, Wikesjö UM. Periodontal regeneration: focus on growth and differentiation factors. Dental clinics of North America. 2010; 54:93-111. [PubMed: 20103474]

73. Lee SB, Retzepi M, Petrie A, Hakimi AR, Schwarz F, Donos N. The effect of diabetes on bone formation following application of the GBR principle with the use of titanium domes. Clinical oral implants research. 2013; 24:28-35. [PubMed: 22432522]

74. Lee J, Stavropoulos A, Susin C, Wikesjö UM. Periodontal regeneration: focus on growth and differentiation factors. Dent Clin North Am. 2010; 54:93-111. [PubMed: 20103474]

75. Lindhe J, Araujo MG, Bufler M, Liljenberg B. Biphasic alloplastic graft used to preserve the dimension of the edentulous ridge: an experimental study in the dog. Clinical oral implants research. 2013; 24:1158-1163. [PubMed: 22804845]

76. Lindhe J, Nyman S, Karring T. Connective tissue reattachment as related to presence or absence of alveolar bone. Journal of clinical periodontology. 1984; 11:33-40. [PubMed: 6363460]

77. Listgarten MA, Mao R, Robinson PJ. Periodontal probing and the relationship of the probe tip to periodontal tissues. Journal of periodontology. 1976; 47:511-513. [PubMed: 1067404]

78. Listgarten MA, Rosenberg MM. Histological study of repair following new attachment procedures in human periodontal lesions. Journal of periodontology. 1979; 50:333-344. [PubMed: 381631]

79. Mardas N, Schwarz F, Petrie A, Hakimi AR, Donos N. The effect of SLActive surface in guided bone formation in osteoporotic-like conditions. Clinical oral implants research. 2011; 22:406-415. [PubMed: 21303420]

80. Mariotti A. Efficacy of chemical root surface modifiers in the treatment of periodontal disease. A systematic review. Annals of periodontology / the American Academy of Periodontol. 2003; 8:205-226.

81. McKenna G, Allen F, Woods N, O’Mahony D, Cronin M, DaMata C, Normand C. Costeffectiveness of tooth replacement strategies for partially dentate elderly: a randomized controlled clinical trial. Community dentistry and oral epidemiology. 2014; 42:366-374. [PubMed: 24251386]

82. Melcher AH. On the repair potential of periodontal tissues. Journal of periodontology. 1976; 47:256-260. [PubMed: 775048]

83. Melcher AH. Repair of wounds in the periodontium of the rat. Influence of periodontal ligament on osteogenesis. Archives of oral biology. 1970; 15:1183-1204. [PubMed: 5280124]

84. Melcher AH. Wound repair in the periodontium of the rat incisor. Archives of oral biology. 1967; 12:1645-1647. [PubMed: 5237343]

85. Moon IS, Berglundh T, Abrahamsson I, Linder E, Lindhe J. The barrier between the keratinized mucosa and the dental implant. An experimental study in the dog. Journal of clinical periodontology. 1999; 26:658-663. [PubMed: 10522777] 
86. Muschler GF, Raut VP, Patterson TE, Wenke JC, Hollinger JO. The design and use of animal models for translational research in bone tissue engineering and regenerative medicine. Tissue engineering Part B, Reviews. 2010; 16:123-145. [PubMed: 19891542]

87. Nabers CL, O'Leary TJ. Autogenous Bone Transplants in the Treatment of Osseous Defects. Journal of periodontology. 1965; 36:5-14. [PubMed: 14258507]

88. Nyman S, Ericsson I, Runstad L, Karring T. The significance of alveolar bone in periodontal disease. An experimental study in the dog. Journal of periodontal research. 1984; 19:520-525. [PubMed: 6238150]

89. Nyman S, Gottlow J, Karring T, Lindhe J. The regenerative potential of the periodontal ligament. An experimental study in the monkey. Journal of clinical periodontology. 1982; 9:257-265. [PubMed: 6954167]

90. Nyman S, Karring T. Regeneration of surgically removed buccal alveolar bone in dogs. Journal of periodontal research. 1979; 14:86-92. [PubMed: 153965]

91. Nyman S, Karring T, Lindhe J, Planten S. Healing following implantation of periodontitis-affected roots into gingival connective tissue. Journal of clinical periodontology. 1980; 7:394-401. [PubMed: 6936413]

92. Nyman S, Lang NP, Buser D, Bragger U. Bone regeneration adjacent to titanium dental implants using guided tissue regeneration: a report of two cases. The International journal of oral \& maxillofacial implants. 1990; 5:9-14. [PubMed: 2391139]

93. Nyman S, Lindhe J, Karring T, Rylander H. New attachment following surgical treatment of human periodontal disease. Journal of clinical periodontology. 1982; 9:290-296. [PubMed: 6964676]

94. Orban B. Pocket elimination or reattachment? The New York state dental journal. 1948; 14:227232. [PubMed: 18861984]

95. Pellegrini G, Seol YJ, Gruber R, Giannobile WV. Pre-clinical models for oral and periodontal reconstructive therapies. Journal of dental research. 2009; 88:1065-1076. [PubMed: 19887682]

96. Piattelli A, Corigliano M, Scarano A, Costigliola G, Paolantonio M. Immediate loading of titanium plasma-sprayed implants: an histologic analysis in monkeys. Journal of periodontology. 1998; 69:321-327. [PubMed: 9579618]

97. Pihlstrom BL, Barnett ML. Design, operation, and interpretation of clinical trials. J Dent Res. 2010; 89:759-772. [PubMed: 20581353]

98. Polson AM, Heijl LC. Osseous repair in infrabony periodontal defects. Journal of clinical periodontology. 1978; 5:13-23. [PubMed: 353083]

99. Prichard J. Regeneration of bone following periodontal therapy; report of cases. Oral surgery, oral medicine, and oral pathology. 1957; 10:247-252.

100. Prichard JF. The etiology, diagnosis and treatment of the intrabony defect. Journal of periodontology. 1967; 38:455-465. [PubMed: 5234632]

101. Proye MP, Polson AM. Repair in different zones of the periodontium after tooth reimplantation. Journal of periodontology. 1982; 53:379-389. [PubMed: 6955500]

102. Renvert S, Polyzois I. Clinical approaches to treat peri-implant mucositis and peri-implantitis. Periodontol 2000. 2015 in press.

103. Retzepi M, Donos N. The effect of diabetes mellitus on osseous healing. Clinical oral implants research. 2010; 21:673-681. [PubMed: 20465554]

104. Reynolds MA, Aichelmann-Reidy ME, Branch-Mays GL, Gunsolley JC. The efficacy of bone replacement grafts in the treatment of periodontal osseous defects. A systematic review. Annals of periodontology/the American Academy of Periodontology. 2003; 8:227-265. [PubMed: 14971256]

105. Robertson PB. Surgical periodontal therapy: indications, selection and limitations. International dental journal. 1983; 33:137-146. [PubMed: 6347904]

106. Robinson E. Osseous coagulum for bone induction. Journal of periodontology. 1969; 40:503-510. [PubMed: 4899855]

107. Romanos GE. Wound healing in immediately loaded implants. Periodontol 2000. 2015 in press. 
108. Romanos GE, Toh CG, Siar CH, Swaminathan D. Histologic and histomorphometric evaluation of peri-implant bone subjected to immediate loading: an experimental study with Macaca fascicularis. The International journal of oral \& maxillofacial implants. 2002; 17:44-51. [PubMed: 11858574]

109. Romanos GE, Toh CG, Siar CH, Wicht H, Yacoob H, Nentwig GH. Bone-implant interface around titanium implants under different loading conditions: a histomorphometrical analysis in the Macaca fascicularis monkey. Journal of periodontology. 2003; 74:1483-1490. [PubMed: 14653395]

110. Romanos GE, Traini T, Johansson CB, Piattelli A. Biologic width and morphologic characteristics of soft tissues around immediately loaded implants: studies performed on human autopsy specimens. Journal of periodontology. 2010; 81:70-78. [PubMed: 20059419]

111. Rosling B, Nyman S, Lindhe J. The effect of systematic plaque control on bone regeneration in infrabony pockets. Journal of clinical periodontology. 1976; 3:38-53. [PubMed: 767366]

112. Salvi GEBD, Lang NP, Abrahamsson I, Berglundh T, Lindhe J, Ivanovski S, Donos N. Temporal sequence of hard and soft tissue healing around titanium dental implants. Periodontol 2000. 2015 in press.

113. Sanz M, Jepsen K, Eikholz P, Jepsen S. Clinical concepts for regenerative therapy in furcations. Periodontol 2000. 2015 (in press).

114. Schaffer EM, Zander HA. Histological evidence of reattachment of periodontal. Parodontologie. 1953; 7:101-107. [PubMed: 13133462]

115. Schar D, Ramseier CA, Eick S, Arweiler NB, Sculean A, Salvi GE. Anti-infective therapy of peri-implantitis with adjunctive local drug delivery or photodynamic therapy: six-month outcomes of a prospective randomized clinical trial. Clinical oral implants research. 2013; 24:104-110. [PubMed: 22568744]

116. Schenk RK, Buser D, Hardwick WR, Dahlin C. Healing pattern of bone regeneration in membrane-protected defects: a histologic study in the canine mandible. The International journal of oral \& maxillofacial implants. 1994; 9:13-29. [PubMed: 8150509]

117. Schmid, B. Good laboratory practice (GLP) in nonclinical investigations. In: Giannobile, WV.; Nevins, M., editors. Osteology guidelines for oral \& maxillofacial regeneration. London: Quintessence; 2011. p. 23-30.

118. Schmitz JP, Hollinger JO. The critical size defect as an experimental model for craniomandibulofacial nonunions. Clinical orthopaedics and related research. 1986:299-308. [PubMed: 3084153]

119. Schwarz F, Aoki A, Becker J, Sculean A. Laser application in non-surgical periodontal therapy: a systematic review. Journal of clinical periodontology. 2008; 35:29-44. [PubMed: 18724840]

120. Schwarz F, Herten M, Sager M, Bieling K, Sculean A, Becker J. Comparison of naturally occurring and ligature-induced peri-implantitis bone defects in humans and dogs. Clinical oral implants research. 2007; 18:161-170. [PubMed: 17348880]

121. Schwarz F, Iglhaut G, Becker J. Quality assessment of reporting of animal studies on pathogenesis and treatment of peri-implant mucositis and peri-implantitis. A systematic review using the ARRIVE guidelines. Journal of clinical periodontology. 2012; 39 (Suppl 12):63-72. [PubMed: 22533947]

122. Schwarz F, Sahm N, Mihatovic I, Golubovic V, Becker J. Surgical therapy of advanced ligatureinduced peri-implantitis defects: cone-beam computed tomographic and histological analysis. Journal of clinical periodontology. 2011; 38:939-949. [PubMed: 21883358]

123. Schwarz F, Sculean A, Engebretson SP, Becker J, Sager M. Animal models for peri-implant mucositis and peri-implantitis. Periodontol 2000. 2015 in press.

124. Sculean AAR, Miron R, Salvi GE, Bosshardt DD. Enamel Matrix Proteins and Periodontal Wound Healing and Regeneration. Clin Adv Periodontics. 2011; 1:101-117.

125. Sculean A, Gruber R, Bosshardt DD. Soft tissue wound healing around teeth and dental implants. Journal of clinical periodontology. 2014; 41 (Suppl 15):S6-22. [PubMed: 24641001]

126. Sculean A, Nikolidakis D, Nikou G, Ivanovic A, Chapple IL, Stavropoulos A. Biomaterials for promoting periodontal regeneration in human intrabony defects. A systematic review. Periodontol 2000. 2015 in press. 
127. Seol YJ, Pellegrini G, Franco LM, Chang PC, Park CH, Giannobile WV. Preclinical methods for the evaluation of periodontal regeneration in vivo. Methods Mol Biol. 2010; 666:285-307. [PubMed: 20717791]

128. Spector, M.; Al-Hezaimi, K.; Nevins, ML. Screening models for tissue engineering. In: Giannobile, WV.; Nevins, M., editors. Osteology guidelines for oral \& maxillofacial regeneration. London: Quintessence; 2011. p. 45-56.

129. Stahl SS. Surgical periodontal therapy. A brief overview. New York state journal of medicine. 1983; 83:66-68. [PubMed: 6572299]

130. Stanford CM. Dental implants. A role in geriatric dentistry for the general practice? J Am Dent Assoc. 2007; 138 (Suppl):34S-40S. [PubMed: 17761844]

131. Stavropoulos A, Sculean A, Bosshardt D, Buser D, Klinge B. Preclinical in vivo models for the screening of bone biomaterials for oral/craniofacial indications: focus on small-animal models. Periodontol 2000. 2015 in press.

132. Stavropoulos A, Wikesjö UM. Growth and differentiation factors for periodontal regeneration: a review on factors with clinical testing. Journal of periodontal research. 2012; 47:545-553. [PubMed: 22486242]

133. Stavropoulos A, Windisch P, Szendroi-Kiss D, Peter R, Gera I, Sculean A. Clinical and histologic evaluation of granular Beta-tricalcium phosphate for the treatment of human intrabony periodontal defects: a report on five cases. Journal of periodontology. 2010; 81:325-334. [PubMed: 20151813]

134. Susin C, Fiorini T, Lee J, De Stefano J, Dickinson DP, Wikesjö UME. Wound healing following surgical and regenerative periodontal therapy. Periodontol 2000. 2015 in press.

135. Takasaki AA, Aoki A, Mizutani K, Schwarz F, Sculean A, Wang CY, Koshy G, Romanos G, Ishikawa I, Izumi Y. Application of antimicrobial photodynamic therapy in periodontal and periimplant diseases. Periodontol 2000. 2009; 51:109-140. [PubMed: 19878472]

136. Vajgel A, Mardas N, Farias BC, Petrie A, Cimoes R, Donos N. A systematic review on the critical size defect model. Clinical oral implants research. 2014; 25:879-893. [PubMed: 23742162]

137. van der Velden U, Jansen J. Probing force in relation to probe penetration into the periodontal tissues in dogs. A microscopic evaluation. Journal of clinical periodontology. 1980; 7:325-327. [PubMed: 6936410]

138. Vignoletti F, Abrahamsson I. Quality of reporting of experimental research in implant dentistry. Critical aspects in design, outcome assessment and model validation. J Clin Periodontol. 2012; 39(12s):6-27. [PubMed: 22533944]

139. Voigt J, Borysiewicz L. Uniting research into human and animal health. Vet Rec. 2010; 166:406407. [PubMed: 20348474]

140. Wade AB. The flap operation. Journal of periodontology. 1966; 37:95-99. [PubMed: 5217767]

141. Weinreb M, Nemcovsky C. In vitro models for the evaluation of wound healing/regeneration. Periodontol 2000. 2015 in press.

142. Wikesjö UM, Selvig KA, Zimmerman G, Nilveus R. Periodontal repair in dogs: healing in experimentally created chronic periodontal defects. J Periodontol. 1991; 62:258-263. [PubMed: 2037956]

143. Wikesjö UM, Sigurdsson TJ, Lee MB, Tatakis DN, Selvig KA. Dynamics of wound healing in periodontal regenerative therapy. J Calif Dent Assoc. 1995; 23:30-35. [PubMed: 9052025]

144. Zucchelli G, Mounssif I. Periodontal plastic surgery. Periodontol 2000. 2015 (in press).

145. Padial-Molina M, Marchesan JT, Taut AD, Jin Q, Giannobile WV, Rios HF. Methods to validate tooth-supporting regenerative procedures. Methods Mol Biol. 2012; 887:135-148. [PubMed: 22566053]

146. Lin Z, Rios HF, Volk SL, Sugai JV, Jin Q, Giannobile WV. Gene expression dynamics during bone healing and osseointegration. J Periodontol. 2011; 82:1007-1017. (out of order). [PubMed: 21142982] 


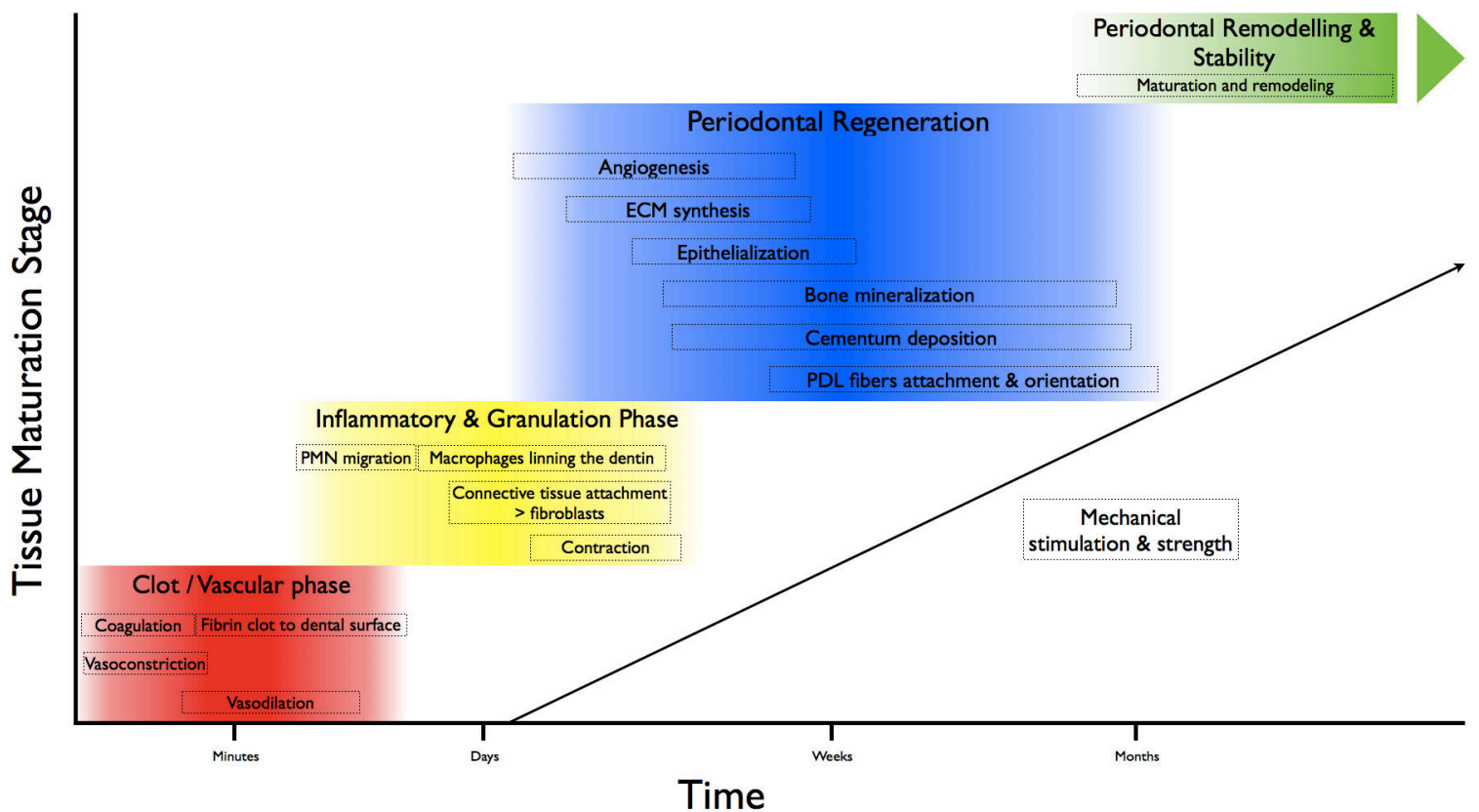

Fig. 1.

Phases during periodontal wound repair and regeneration. Reproduced from Humana Press, with permission (Adapted from 146). 


\section{THE TRANSLATIONAL CONTINUUM FOR ORAL HEALTH RESEARCH}

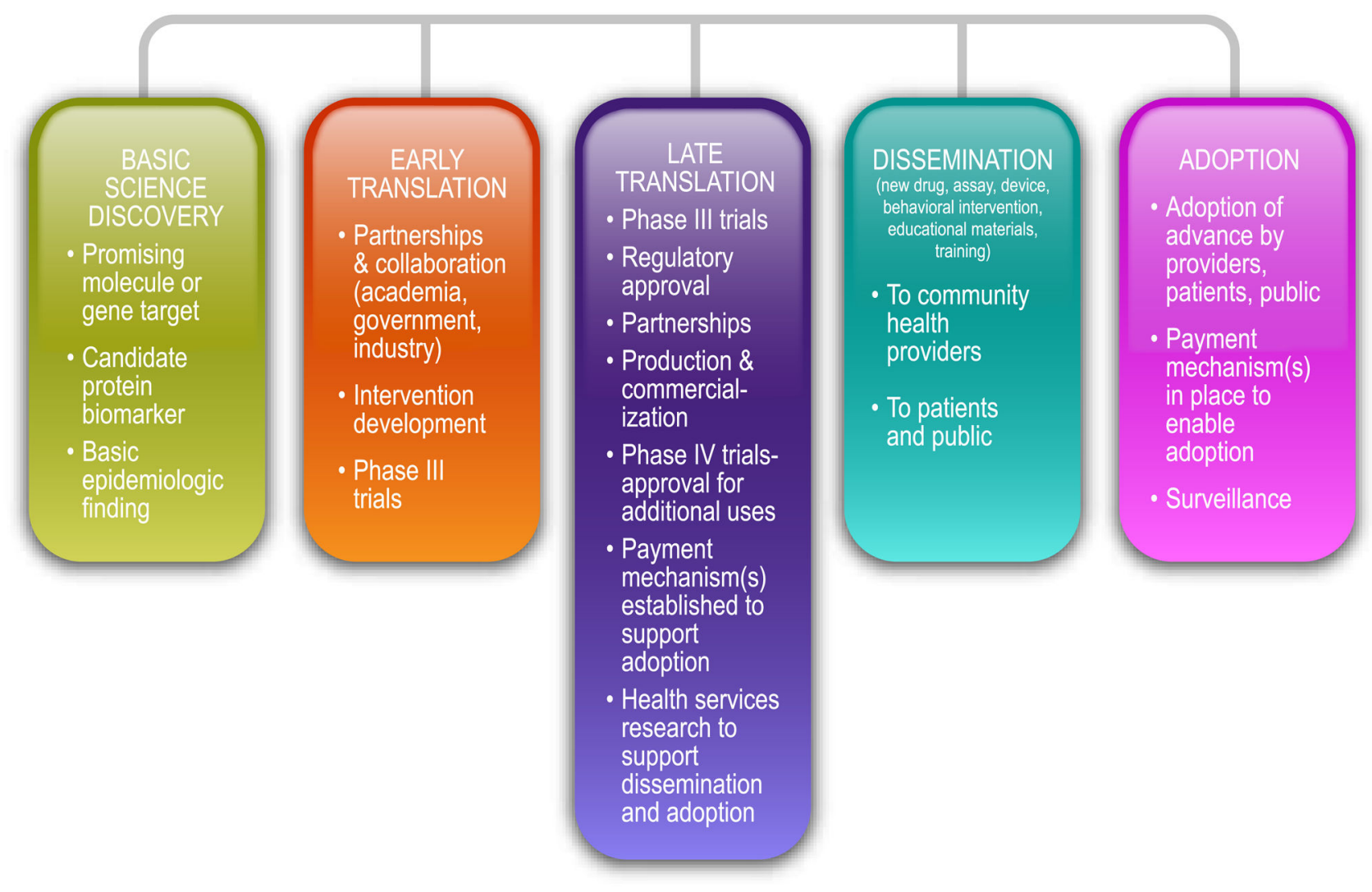

Fig. 2.

The translational continuum from laboratory research discovery, to preclinical animal model testing and eventual acceptance to clinical practice. Reproduced from Quintessence Publishing, with permission (From 46, with permission). 


\section{Table 1}

\section{Advantages and disadvantages of rat defect models}

\begin{tabular}{|c|c|c|}
\hline Defect Type & Advantages & Disadvantages \\
\hline Fenestration (periodontal) & $\begin{array}{l}\text { - } \quad \text { gives a proof-of-concept in a short interval } \\
\text { - } \quad \text { well-contained defects } \\
\text { - no gingival tissue ingrowth }\end{array}$ & $\begin{array}{l}\text { - } \quad \text { narrow healing window } \\
\text { - } \quad \text { small size, surgical microscopes } \\
\text { required } \\
\text { - } \quad \text { spontaneous healing }\end{array}$ \\
\hline Capsule (vertical ridge) & $\begin{array}{l}\text { - } \quad \text { standardized shape-dimension } \\
\text { - } \quad \text { shielded from local environment } \\
\text { filled solely with cells and fluids emanating } \\
\text { from the residual bone }\end{array}$ & $\begin{array}{l}\text { - } \\
\text { - } \quad \text { isolation from oral environment } \\
\text { - } \quad \text { spontaneous regeneration } \\
\text { - } \quad \text { formation of bone outside the capsule }\end{array}$ \\
\hline Alveolar socket & $\begin{array}{l}\text { - } \\
\text { - } \quad \text { reproduce well the events occurring in bone } \\
\text { healing }\end{array}$ & $\begin{array}{l}\text { - } \quad \text { small size } \\
\text { - } \quad \text { rapid bone repair compared to human }\end{array}$ \\
\hline Infrabony peri-implant defect & $\begin{array}{l}\text { Surgically created } \\
\text { - } \quad \text { short-time needed to be generated defect } \\
\text { - } \quad \text { standard morphology-dimension }\end{array}$ & $\begin{array}{l}\text { Surgically created } \\
\text { - } \quad \text { spontaneous regeneration } \\
\text { - narrow evaluation window }\end{array}$ \\
\hline
\end{tabular}

Reproduced from (95), with permission. 
Table 2

Advantages and disadvantages of large animals defect models

\begin{tabular}{|c|c|c|c|}
\hline Defect Type & Animal Model & Advantages & Disadvantages \\
\hline Furcation/infrabony periodontal defect & Dog \& Monkey & $\begin{array}{ll}\text { Surgical Acute-chronic } \\
\text { - } & \begin{array}{l}\text { short time to be } \\
\text { created-less } \\
\text { expensive }\end{array} \\
\text { - } & \begin{array}{l}\text { standardized } \\
\text { morphological } \\
\text { characteristics }\end{array} \\
\text { - } & \begin{array}{l}\text { do not regenerate } \\
\text { spontaneously } \\
\text { (chronic) }\end{array} \\
\text { - } \quad & \text { class II-III } \\
\text { furcation } \\
\text { - } \quad \begin{array}{l}\text { bilateral similar } \\
\text { defect }\end{array} \\
\text { - } \quad \begin{array}{l}\text { horizontal defect } \\
\text { allows an } \\
\text { estimation of the } \\
\text { origin of the newly } \\
\text { formed tissue }\end{array} \\
\text { - } \quad \begin{array}{l}\text { solid database } \\
\text { describing healing } \\
\text { (dog) }\end{array} \\
\text { minimal palatal } \\
\text { recession (monkey) }\end{array}$ & $\begin{array}{ll}\text { Surgical Acute } \\
\text { - } \quad \begin{array}{l}\text { do not reproduce inflammatory/ } \\
\text { infective conditions }\end{array} \\
\text { - } \quad \begin{array}{l}\text { spontaneous partial regeneration } \\
\text { (monkey) }\end{array} \\
\text { Surgical Chronic } \\
\text { - } \quad \text { soft tissues compromised } \\
\text { - } \quad \begin{array}{l}\text { variable amount of connective } \\
\text { tissue regeneration }\end{array} \\
\text { Ligature-induced } \\
\text { - } \quad \begin{array}{l}\text { non-predictable disease } \\
\text { development }\end{array} \\
\text { non-standardized defect } \\
\text { morphology (dog) } \\
\text { require time to be created \& } \\
\text { expensive }\end{array}$ \\
\hline
\end{tabular}

Ligature-induced

- microbiological features similar to humans

- morphological

features similar to humans

- do not regenerate spontaneously

- can make similar lesions as control in contralateral defects

\begin{tabular}{llll}
\hline Alveolar socket $\quad$ Dog \& Monkey & $\begin{array}{l}\text { easy and fast to } \\
\text { perform }\end{array}$ & $\bullet \quad \begin{array}{l}\text { rapid bone repair compared to } \\
\text { human }(\operatorname{dog})\end{array}$ \\
& $\bullet \quad \begin{array}{l}\text { reproduce well the } \\
\text { events occurring in } \\
\text { bone healing }\end{array}$ \\
\end{tabular}

Dog \& Monkey Surgically created

- $\quad$ short-time needed to be generated defect

- $\quad$ standard morphologydimension

Ligature-induced
Surgically created

- $\quad$ spontaneous regeneration

Ligature-induced

- $\quad$ spontaneous partial regeneration

- $\quad$ long time required to generate defect

- morphological and microbiological 


\begin{tabular}{llll}
\hline Defect Type & Animal Model & Advantages & Disadvantages \\
\hline & & $\begin{array}{l}\text { similarities with } \\
\text { humans }\end{array}$ & \\
\hline Supra-alveolar peri-implant defect & Dog & $\bullet$ & $\begin{array}{l}\text { limited spontaneous } \\
\text { regeneration } \\
\text { reproducibly } \\
\text { created }\end{array}$ \\
\hline
\end{tabular}

Reproduced from (95), with permission. 